\title{
IDENTIFICATION OF FORMALDEHYDE IN UNBRANDED WET NOODLES AT TRADITIONAL MARKETS OF TAMBUN SELATAN USING TEST KIT METHODS AND UV-VIS SPECTROPHOTOMETRY
}

\author{
Wilis Rarabiella ${ }^{1}$, Elfira Maya Sari ${ }^{2}$, Siti Nurfajriah $^{3}$ \\ 1. Department of Medical Laboratory Technology, STIKes Mitra Keluarga, Bekasi -Indonesia \\ 2. Department of Medical Laboratory Technology, STIKes Mitra Keluarga, Bekasi -Indonesia \\ 3. Department of Medical Laboratory Technology, STIKes Mitra Keluarga, Bekasi -Indonesia
}

*Correspondence: Wilis Rarabiella | STIKes Mitra Keluarga|wilisrarabiella@yahoo.com

\begin{abstract}
Introduction: Wet noodles are flour-based foods that are widely consumed by the community because of their easy processing. The high water content in wet noodles makes the noodles not last long. In fact, there is still a preservative in wet noodles that is not used, namely formaldehyde. The purpose of this study was to determine whether there was formaldehyde in unbranded wet noodles in the Traditional Market of South Tambun District and to determine the level of formaldehyde in unbranded noodles in the Traditional Market of South Tambun District.

Method: This research was conducted at the STIKes Mitra Keluarga laboratory. The type of research used is descriptive. There are 7 samples taken from 4 different markets. The sample was tested using a formaldehyde test kit and resulted in 6 positive formaldehyde samples. According to SNI, formaldehyde should not be in wet noodles. So that the results of the 6 samples did not meet the quality requirements of wet noodles.

Results: Furthermore, the positive sample was determined using a UV-VIS spectrophotometer and Nash reagent. The lowest level of formaldehyde is $18.61 \mathrm{mg} / \mathrm{L}$ while the highest level is $738.45 \mathrm{mg} / \mathrm{L}$.

Conclusion: First, the regulation is not yet known by the producers because it is classified as traditional. Second, there is no good control from authorized institutions or officers. Third, the lack of guidance for producers

Keywords: Formaldehyde, Wet Noodles, UV-VIS Spektrofotometry, Formaldehyde Test Kit.
\end{abstract}

Received November 26, 2021; Accepted December 30, 2021

\section{INTRODUCTION}

Food is an important part of human life which is largely influenced by environmental factors related to human health. Cheap food is not necessarily safe for consumption by consumers, especially processed foods found in public places so that one of them can be contaminated with dangerous chemicals. Many processed foods such as noodles, meatballs, nuggets, and fish definitely require preservatives. One of the chemicals that are often used in food preservation is formaldehyde (Male \& Letsoin, 2018). Wet noodles are flour-based foods that are widely consumed by the community because of their easy processing.

Wet noodles are easy to find and liked by many people (Nani \& Wibowo, 2019). Wet noodles are widely sold in markets and mobile vegetable traders, usually used as a complement to other foods, namely meatballs, lontong noodles, kopyok noodles and other types of food. Wet noodles have a water content of around $52-60 \%$, therefore due to the high water content, wet noodles do not last long (Yulianti \& Aldila, 2020).

The shelf life of noodles can be extended by adding preservatives to the food. In fact, there are still preservatives found in wet noodles that should not be used, namely formaldehyde (Yulianti \& Aldila, 2020). formaldehyde is one of the non-food preservatives that is widely misused to preserve food. Besides being used as a formaldehyde disinfectant, it is also used as a corpse preservative (Roswiem \& Septiani, 2018).

According to the Regulation of the Minister of Health of the Republic of Indonesia Number $1168 /$ Menkes/PER/X/1999, it is explained that formaldehyde is one of the food additives that is prohibited from using it (Syarfaini \& Rusmin, 2014). The use of formaldehyde in food can cause acute and chronic effects that can attack the respiratory tract, digestion, headaches, seizures, unconsciousness and coma. The use of formaldehyde can also cause damage to the liver, heart, brain, spleen, pancreas, central nervous system and kidneys (Asyfiradayati et al., 2019). 


\section{METHOD}

\section{Types of research}

The type of research that will be conducted is descriptive. According to Masturoh \& Nauri (2018) descriptive research is research to describe phenomena that occur in certain populations. In the health sector, descriptive research is used to describe health problems that occur in a particular community or community.

\section{Research Time and Place}

The time of the study was carried out in February-April 2021. The place of research was carried out at the Mitra Keluarga STIKes Laboratory

\section{Tools and materials}

The tools used were Genesys 10s UV-VIS Spectrophotometry, Antiline Test Kit, analytical balance, measuring flask, measuring cup, test tube, beaker glass, erlenmeyer, stirring rod, watch glass, pipette, kyu clamp, and water bath. The ingredients used are unbranded wet noodles, ammonium acetate (Merck, acetyl acetone (Emsure), acetic acid (Emsure), distilled water, and 37\% formaldehyde).

\section{Ways of working}

Organoleptic observations were carried out by observing the smell, texture, and shape of the wet noodles. Observations of wet noodles will be carried out on each sample. The data obtained will be processed in tabular form.

Qualitative tests with test kits were carried out by weighing $10 \mathrm{~g}$ of the sample and then blending it. The sample was added with $20 \mathrm{ml}$ of hot water and allowed to cool. The sample was filtered to obtain a sample filtrate. $5 \mathrm{~mL}$ of filtrate was put into a test tube. 4 drops of reagents A and B were added to the filtrate, then homogenized. Notice the color change that forms. Samples containing formaldehyde will change color from clear to pink to purple.

Quantitative test using spectrophotometry begins with the manufacture of Nash reagent. Preparation of Nash reagent by preparing $15 \mathrm{~g}$ of ammonium acetate and adding $0.3 \mathrm{ml}$ of acetic acid. Then $0.2 \mathrm{ml}$ of acetyl acetone and distilled water were added until the volume was $100 \mathrm{ml}$. After making the Nash rectifier, it was continued with the preparation of a mother liquor of $6 \mathrm{mg} / \mathrm{mL}$ formaldehyde by pipetting $1.1 \mathrm{ml}$ of $37 \%$ formaldehyde in a $200 \mathrm{ml}$ volumetric flask. Aquades is added to the limit mark.

The manufacture of formaldehyde standard solution is done by making a standard solution of formaldehyde with concentrations of $100 \mathrm{ppm}, 150 \mathrm{ppm}, 200 \mathrm{ppm}, 250 \mathrm{ppm}$, and $300 \mathrm{ppm}$. The mother liquor was pipetted sequentially as much as $1.7 \mathrm{ml}, 2.5 \mathrm{ml}, 3.3 \mathrm{ml}, 4.2 \mathrm{ml}$, and $5 \mathrm{ml}$ into a $100 \mathrm{ml}$ volumetric flask. The solution was added with distilled water up to the limit mark.

Determination of maximum wavelength with Nash reagent using Formaldehyde concentration of 150 ppm was pipetted $1 \mathrm{ml}$ and put in a closed test tube. The test tube was added with $10 \mathrm{ml}$ of water and $5 \mathrm{ml}$ of Nash reagent. The test tube was heated at 37 for 30 minutes. The test tube was cooled, then transferred to a $25 \mathrm{ml}$ volumetric flask and adjusted the volume to 20 with distilled water and observed the absorption at a wavelength of $400-500 \mathrm{~nm}$.

Standard formaldehyde measurements were carried out to determine the calibration curve. Standard formaldehyde measurements were carried out by pipetting $1 \mathrm{ml}$ of $100 \mathrm{ppm}$ formaldehyde solution into a closed test tube and adding up to $10 \mathrm{ml}$ of water and $5 \mathrm{ml}$ of Nash reagent. The test tube was heated on a water bath at $37^{\circ} \mathrm{C}$ for 30 minutes.

The mixture was transferred to a $25 \mathrm{ml}$ volumetric flask and cooled. After cooling, adjust the volume using water and shake until homogeneous. The absorption was observed at a wavelength of $414 \mathrm{~nm}$. At concentrations of 150,200, 250 and $300 \mathrm{ppm}$ the same method was carried out.

Wet noodle samples were tested by weighing 5 grams of the sample and putting it in a closed erlenmeyer. The sample was added $50 \mathrm{ml}$ of distilled water. The wet noodle sample was heated for 1 hour at a temperature of $40 \pm 2$ while being shaken for 1 minute every 5 minutes. After being heated, the sample was cooled, then the wet noodle sample was filtered into a $100 \mathrm{ml}$ volumetric flask. The volume is made up to the mark using residual rinse water. 
Do the same way 3 times for each sample. The sample was pipetted $5 \mathrm{ml}$ of the filtrate into a $10 \mathrm{ml}$ volumetric flask. The volume was made up using Nash's reagent to the limit mark. The sample was heated for 30 minutes at $40^{\circ} \mathrm{C}$. After cooling the sample at room temperature for 30 minutes and measuring the level of formaldehyde using UV-Vis spectrophotometry.

\section{RESULTS}

Wet noodles are noodles that have a high water content. Wet noodles can last a long time if added preservatives to extend the shelf life of noodles. In addition, noodles can be stored for a long time. formaldehyde is a hazardous chemical whose use is still ongoing today. Sampling was carried out on 4 markets in South Tambun District, namely Mini Market, Rawa Kalong Market, Tambun Market, and Graha Prima Market. The number of samples obtained is 7 samples. The sample is a noodle product that is produced in several places in the cities of Bekasi and Cikarang. The noodles produced are then distributed in several traditional markets in South Tambun District. Even though they are the same in the location where they pick up the noodles, the traders admit that they are different in picking the distributors. Further testing is carried out using a test kit. Positive results will be followed by using UV-Vis Spectrophotometry.

\section{Organoleptic Observations}

Organoleptic testing aims to give an impression with the senses and react to the stimuli received. These abilities include the ability to detect, recognize, differentiate, compare and express likes and dislikes (Physical Quality Handling Module, 2013). The results of organoleptic observations on 7 samples were based on the texture, smell, and shape of the noodles.

Table 1 Organoleptic Observations

\begin{tabular}{|c|c|c|c|}
\hline No. & Sample code & Desciption & Noodle Sample \\
\hline 1 & $\mathrm{GH}$ & $\begin{array}{l}\text { Smell: not the typical noodle smell and } \\
\text { pungent } \\
\text { Texture: not sticky, hard to break, oily } \\
\text { noodles, not easy to crumble } \\
\text { Noodle shape: small noodle size }\end{array}$ & \\
\hline 2 & RK & $\begin{array}{l}\text { Smell: not the typical noodle smell and } \\
\text { pungent. } \\
\text { Texture: not sticky, hard to break noodles } \\
\text { very oily, not easy to crumble. } \\
\text { Noodle shape: the size of the noodles is a } \\
\text { little big. }\end{array}$ & \\
\hline 3 & PM & $\begin{array}{l}\text { Smell: not the typical noodle smell and } \\
\text { pungent } \\
\text { Texture: not sticky, hard to break the } \\
\text { noodles are very oily, not easy to crumble } \\
\text { Noodle shape: the size of the noodles is a } \\
\text { little big. }\end{array}$ & \\
\hline 4 & PT 1 & $\begin{array}{l}\text { Smell: typical noodle smell (not } \\
\text { overpowering). Texture: easy to break, } \\
\text { slightly runny noodles, non-sticky noodles, } \\
\text { easy to crumble. Noodle shape: the size of } \\
\text { the noodles is large. }\end{array}$ & \\
\hline 5 & PT 2 & $\begin{array}{l}\text { Smell: not the typical noodle smell and } \\
\text { pungent. } \\
\text { Texture: not sticky, hard to break noodles } \\
\text { very oily, not easy to crumble. } \\
\text { Noodle shape: the size of the noodles is } \\
\text { small. }\end{array}$ & \\
\hline
\end{tabular}




\begin{tabular}{lll}
\hline 6 & PT 3 & $\begin{array}{l}\text { Smell: not the typical noodle smell and } \\
\text { pungent. } \\
\text { Texture: not sticky, hard to break noodles } \\
\text { very oily, not easy to crumble. } \\
\text { Noodle shape: the size of the noodles is } \\
\text { small. }\end{array}$ \\
& $\begin{array}{l}\text { Smell: not the typical noodle smell and } \\
\text { pungent. } \\
\text { Texture: not sticky, hard to break noodles } \\
\text { very oily, not easy to crumble. } \\
\text { Noodle shape: the size of the noodles is } \\
\text { small. }\end{array}$ \\
\hline
\end{tabular}

\section{Qualitative testing using Test kit}

Qualitative testing was carried out using a test kit to see the presence or absence of formaldehyde in wet noodles. In table 4.2, the results show that from the 7 Wet noodle samples obtained $6(86 \%)$ positive samples containing formaldehyde with sample codes GH, RK, PM, PT2, PT3, and PT4. While 1 (14\%) sample is negative with the sample code PT1. Samples tested positive for formaldehyde if the color changes to purple. The formation of purple color occurs due to the reaction between the reagent and formaldehyde in the sample.

Table 2. Qualitative Testing with Test Kit

\begin{tabular}{ccccc}
\hline No. & Market Name & Sample codes & Discoloration & Description \\
\hline 1. & Graha Prima & GH & Yellow-Purple & Positif (+) \\
2. & Rawakalong & RK & Yellow-Purple & Positif (+) \\
3. & Pasar Mini & PM & Yellow-Purple & Positif (+) \\
4. & Pasar Tambun & PT 1 & Yellow-Yellow & Negatif $(-)$ \\
5. & Pasar Tambun & PT 2 & Yellow-Purple & Positif (+) \\
6. & Pasar Tambun & PT 3 & Yellow-Purple & Positif (+) \\
7. & Pasar Tambun & PT 4 & Yellow-Purple & Positif (+) \\
\hline
\end{tabular}

Table 3. Results of Calculation of formaldehyde Levels

\begin{tabular}{cccc}
\hline No. & Sample Codes & Average absorbance $(\mathbf{n m})$ & Average level $(\mathbf{m g} / \mathbf{L})$ \\
\hline 1. & PT 3 & 0,008 & 18,455 \\
2. & PT 4 & 0,050 & 37,545 \\
3. & PT 2 & 0,721 & 342,545 \\
4. & RK & 0,724 & 343,909 \\
5. & PM & 1,232 & 574,818 \\
6. & GH & 1,592 & 738,455 \\
\hline
\end{tabular}

The results of measuring the level of formaldehyde in the sample of wet noodles in the sample code PT obtained an average absorbance of $0.008 \mathrm{~nm}$ with an average level of formaldehyde in the sample of 18.455 $\mathrm{mg} / \mathrm{L}$. In the sample code PT 4, an average absorbance of $0.050 \mathrm{~nm}$ was obtained with an average level of formaldehyde in the sample of $37.545 \mathrm{mg} / \mathrm{L}$.

\section{DISCUSSION}

The results of organoleptic testing aim to give an impression with the senses and provide a reaction to the stimuli received. These abilities include the ability to detect, recognize, differentiate, compare and express likes and dislikes (Physical Quality Handling Module, 2013). The results of organoleptic observations on 7 samples were based on the texture, smell, and shape of the noodles.

The results of organoleptic observations in table 4.1 that formaldehyde noodles have almost the same smell and texture of wet noodles, namely, the samples coded for GH, RK, PM, PT2, PT3, and PT4. There are differences in the smell and texture of the wet noodles that are not formaldehyde, namely the PT1 wet 
noodle sample.

Wet noodles with sample code PT1 have a typical noodle odor and are not overpowering (the smell is not like medicine). Noodles break easily and noodles don't look like they've been greased. While the samples of GH, PM, PT2, PT3, and PT4 produced a pungent odor (smells like medicine) and the noodles did not break easily when pulled. Wet noodles on samples of GH, RK, PM, PT2, PT3, and PT4 looked like they had been smeared with oil. The RK, PM and PT4 samples showed very oily noodles.

Formaldehyde wet noodles have the characteristics of looking shiny, not easy to break, not sticky, and smells like medicine (Yulianti, C.H, 2020). Meanwhile, the characteristics of non-formaldehyde noodles are that the smell is not strong, the noodles are not shiny, and they break easily (Tamsil et al., 2020). Organoleptic observations cannot confirm that the noodles are free of formaldehyde. Determination of formaldehyde noodles continued with qualitative testing with a test kit and UV-Vis spectrophotometry to determine the level of formaldehyde.

The results of qualitative testing were carried out using a test kit to see the presence or absence of formaldehyde in wet noodles. Table 4.2 shows that of the 7 samples of wet noodles, $6(86 \%)$ positive samples contained formaldehyde with sample codes GH, RK, PM, PT2, PT3, and PT4. While 1 (14\%) sample is negative with the sample code PT1. Samples tested positive for formaldehyde if the color changes to purple. The formation of purple color occurs due to the reaction between the reagent and formaldehyde in the sample.

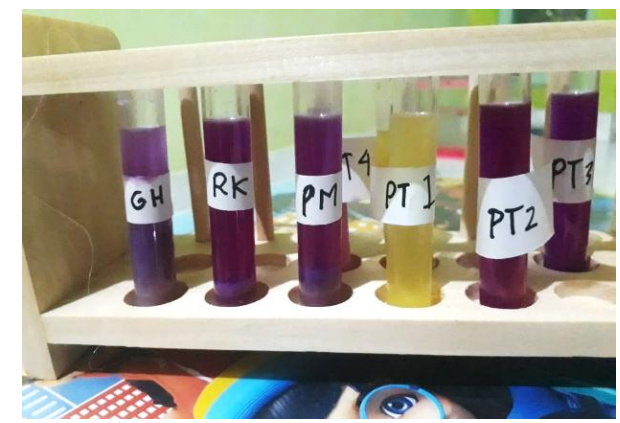

Figure 1 Qualitative Test of GH, RK, PM, PT 1, PT 2 . Samples

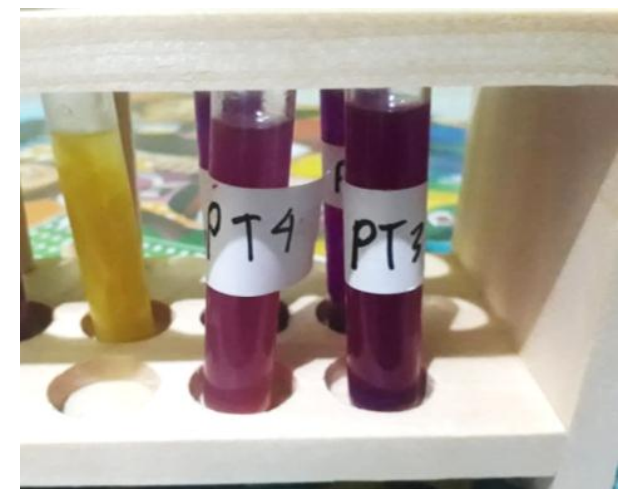

Figure 2 Sample Qualitative Test PT4, PT3

formaldehyde test kit is a tool used for rapid testing of formaldehyde content in food and beverages, as well as fishery products. The test kit consists of 2 reagents namely; Reagent A containing pararosanilin dye solution with a concentration of $0.05-0.2 \%$ and sodium metabisulfite solution $0.5-5 \%$ and Reagent B containing 25\% Hydrochloric Acid solution. Pararosanilin with saturated sulfite in an acidic environment will react with the formaldehyde present in the sample. The reaction will form a purple pararosaniline formaldehyde complex. 


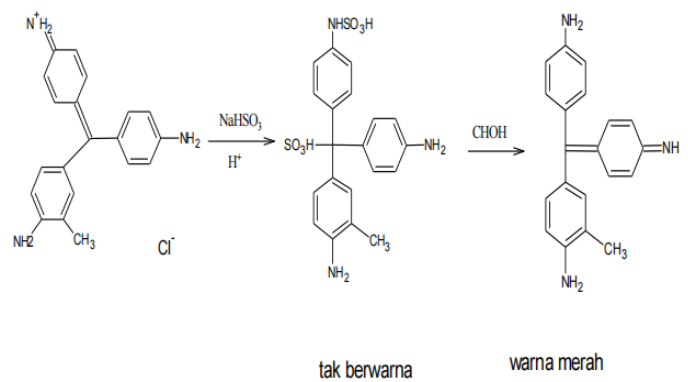

Figure 3 formaldehyde Reaction Equation with Test Kit (Junaini et al., 2016)

Qualitative testing of wet noodle formaldehyde using an antiline test kit. The antiline test kit uses the Schiff method to detect the presence of formaldehyde in the sample. Antiline test kits can detect a minimum of $2 \mathrm{ppm}$ formaldehyde found in food in solid or liquid form. Schiff's reagent will produce a purple color when formaldehyde is detected in the sample based on the sulfonation reaction (Syafitri et al., 2012).

\section{Determination of formaldehyde Levels with UV-VIS. Spectrophotometry}

Determination of formaldehyde content in wet noodles was carried out using UV-Vis Spectrophotometry. Prior to the determination of the concentration, a Nash reagent consisting of ammonium acetate, acetic acid and acetyl acetone was made first. Furthermore, $6 \mathrm{mg} / \mathrm{ml}$ formaldehyde mother liquor and standard solutions of $100 \mathrm{ppm}, 150 \mathrm{ppm}, 200 \mathrm{ppm}, 250 \mathrm{ppm}$ and $300 \mathrm{ppm}$ were made. The determination of the wavelength was carried out using a standard solution of $150 \mathrm{ppm}$. The absorption was observed at 400-416 nm UV-Vis spectrophotometry.

\section{Determination of Maximum Wavelength}

Determination of the maximum wavelength using $150 \mathrm{ppm}$ formaldehyde solution. $150 \mathrm{ppm}$ formaldehyde solution was reacted with Nash reagent and heated at $37^{\circ} \mathrm{C}$ for 30 minutes. After the cold solution is then transferred to a $25 \mathrm{ml}$ volumetric flask and adjust the volume with distilled water. Absorption was observed at the wavelength 400-416. At wavelength 400-416 there is still an increase in wavelength. At wavelength 416 there has been a decrease in the maximum wavelength. Based on these measurements obtained the maximum wavelength at $414 \mathrm{~nm}$.

Table 4. 3 Determination of Maximum Wavelength

\begin{tabular}{cc}
\hline Panjang Gelombang & Absorbansi \\
\hline 402 & 0,374 \\
404 & 0,382 \\
406 & 0,389 \\
408 & 0,394 \\
410 & 0,398 \\
412 & 0,400 \\
414 & 0,401 \\
\hline
\end{tabular}

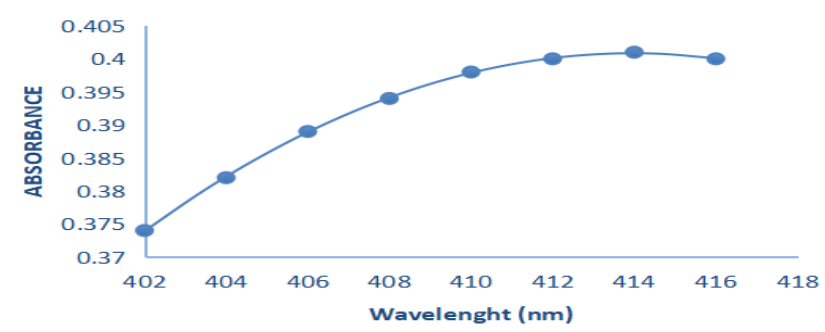

Figure 4 Maximum Wavelength Graph 
Based on Roswiem's research (2018), the maximum wavelength is $413 \mathrm{~nm}$. When compared with this study, there is a change in the maximum wavelength. However, according to Susanti (2010) formaldehyde has an optimum absorption at $412-415 \mathrm{~nm}$. So that the wavelength of $414 \mathrm{~nm}$ can still be used to measure formaldehyde in the sample. At a wavelength of 400-500 the visible color is green-yellow and the absorbed color is purple (Zackiyah, 2016).

\section{Determination of the Calibration Curve}

Determination of the calibration curve using standard solution concentrations, namely $100 \mathrm{ppm}, 150$ ppm, $200 \mathrm{ppm}, 250 \mathrm{ppm}$, and $300 \mathrm{ppm}$. A calibration curve is used to show the relationship between concentration and calibration. The greater the standard concentration, the higher the absorbance (Yulianti, C.H, 2020).

Table 4. 4 Determination of the Standard Curve

\begin{tabular}{cc}
\hline Concentration (ppm) & Absorbance (A) \\
\hline 0 & 0 \\
100 & 0,149 \\
150 & 0,293 \\
200 & 0,383 \\
250 & 0,552 \\
300 & 0,637 \\
\hline
\end{tabular}

Based on the data in table 4.4, the absorption results at the five concentrations are $0,100 \mathrm{ppm}, 150$ ppm, $200 \mathrm{ppm}, 250 \mathrm{ppm}$, and $300 \mathrm{ppm}$ showing absorbance values of $0,0.149,0.293,0.383,0.552$, and 0.637. The calibration curve equation is used to show the relationship between the $\mathrm{x}$ and $\mathrm{y}$ axes. The linear regression equation obtained is $\mathrm{y}=0.0022 \mathrm{x}-0.0326$ with a correlation coefficient of $\mathrm{R} 2=0.9847$. The curve is said to be linear if the correlation coefficient is 0.98 (Yulianti, C.H, 2020). Based on this, it states that the results of the curve coefficients meet the requirements.

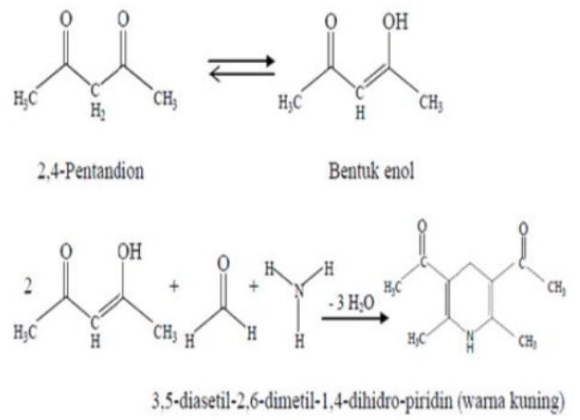

Figure 5 Reaction Equation between formaldehyde and Nash Reagent (Umbingo et al., 2015)

Nash reagent can give color to a colorless formaldehyde solution. The addition of Nash reagent will turn the solution yellow because it is hydrolyzed to the enol form after heating. The darker the color, the higher the concentration due to the greater amount of analyte in the solution (Umbingo et al., 2015).

\section{Calculation of formaldehyde levels in samples using UV-VIS . Spectrophotometry}

The results of measuring the level of formaldehyde in the sample of wet noodles in the sample code PT obtained an average absorbance of $0.008 \mathrm{~nm}$ with an average level of formaldehyde in the sample of 18.455 $\mathrm{mg} / \mathrm{L}$. In the sample code PT 4, an average absorbance of $0.050 \mathrm{~nm}$ was obtained with an average level of formaldehyde in the sample of $37.545 \mathrm{mg} / \mathrm{L}$. While the sample code PT 2, RK, PM, and GH the average absorbance results passed the standard, namely $0.637 \mathrm{~nm}$. It is recommended that the four samples be diluted first because of the high levels of formaldehyde in the sample.

According to the International Program on Chemical Safety (IPCS) in general, the safe threshold for formaldehyde in the body is $1 \mathrm{mg} / \mathrm{L}$ (Nababan et al., 2019). Meanwhile, according to SNI (2015) 
formaldehyde should not be in wet noodles. Based on this, the 6 samples did not meet the quality requirements of wet noodles and exceeded the safe threshold.

Based on research that has been done and research conducted by Indriani \& Suwita (2018), Krisnawati (2018), and the findings of cases of formaldehyde use in wet noodle producers in Bekasi in 2017 show that there are still many wet noodle traders who use preservatives that are not allowed. namely formaldehyde. The use of formaldehyde is prohibited in the Regulation of the Minister of Health of the Republic of Indonesia No. 722/Menkes/Per/88 concerning Food Additives. formaldehyde is prohibited from being used in food because it has an effect on health. The effects of using formaldehyde can be felt after several years. High formaldehyde content can cause gastric irritation and is carcinogenic.

There are several possibilities that there are still many who violate the Regulation of the Minister of Health of the Republic of Indonesia No. 722/Menkes/Per/88. First, the regulation is not yet known by the producers because it is classified as traditional. Second, there is no good control from authorized institutions or officers. Third, the lack of guidance for producers (Nababan et al., 2019).

\section{REFERENCE}

[BPOM] Badan Pengawas Obat dan Makanan Republik Indonesia. (2013). Peraturan Kepala Badan Pengawas Obat Dan Makanan Republik Indonesia Nomor 36 Tahun 2013 Tentang Batas Maksimum Penggunaan Bahan Tambahan Pangan Pengawet.

[BPOM] Badan Pengawasan Obat dan Makanan Republik Indonesia. (2008). formaldehyde (Larutan Formaldehid).

[Kemenkes RI] Kementrian Keseharan RI. (2012). Peraturan Menteri Kesehatan RI Nomor 033 tahun 2012 tentang Bahan Tambahan Pangan. Kementrian Kesehatan RI, Nomor. 033, 3,13-37.

Abdulmumeen, H. A., Risikat, A. N., \& Sururah, A. R. (2012). Food: Its preservatives, additives and applications. Ijcbs, 1, 36-47.

Asyfiradayati, R., Ningtyas, A., Lizansari, M., Purwati, Y., \& Winarsih, W. (2019). Identifikasi Kandungan formaldehyde Pada Bahan Pangan (Mie Basah, Bandeng Segar dan Presto, Ikan Asin, Tahu) di Pasar Gede Kota Surakarta. Jurnal Kesehatan, 11(2).

BRSDM. (2013). Rekomendasi Teknologi Kelautan dan Perikanan. http://brsdm.kkp.go.id/_pub/files34925Buku Rekomendasi Teknologi KP 2013.pdf

Cahyadi, W. (2012). Bahan Tambahan Pangan (2nd ed.). Bumi Aksara.

Chemical Inc Laboratory. (2005). Material Safety Data Sheet ( MSDS ): Formaldehyde.

Dwi Agustiningrum, S., Kusuma Wardani, N., \& Nurindah Alifianti, N. (2018). Foods Containing formaldehyde And Chlorine In The East Surabaya Area. ICASH Research for Better Society, 3, 348 355.

Fadilah, R. (2017). Bahan Ajar "Bahan Tambahan Makanan” (pp. 9-28).

Indriani, A. D., \& Suwita, I. K. (2018). Keamanan Pangan Mie Basah Kuning ( Kandungan Boraks , formaldehyde, Methanil yellow ) Di Beberapa Pasar Tradisional Kota MALANG. Jurnal Gizi KH, $1(1), 42-51$.

Irawan, A. (2019). Kalibrasi Spektrofotometer Sebagai Penjaminan Mutu Hasil Pengukuran Dalam Kegiatan Penelitian Dan Pengujian. Indonesian Journal of Laboratory, 1(2), 1-9.

J.K Negara et al. (2016). Aspek mikrobiologis, serta Sensori (Rasa, Warna,Tekstur, Aroma) Pada Dua Bentuk Penyajian Keju yang Berbeda. Jurnal Ilmu Produksi Dan Teknologi Hasil Peternakan, 4(2), 286-290.

Junaini, Wibowo, M. A., \& Riyanto, R. (2016). Uji Kualitatif Kandungan Formaldehid Alami pada Ikan Patin Jambal (Pangasius djambal) Selama Penyimpanan Suhu Dingin Menggunakan Test Kit Antilin. $J K K, 5(3), 8-12$.

Kamruzzaman, M. (2016). formaldehyde Crime in Bangladesh: A Case Study. European Journal of Clinical and Biomedical Sciences, 2(5), 39-44.

Koswara, S. (2009). Teknologi pengolahan mie. EBookpangan.Com, h 2.

Krisnawati, M. (2018). Penetapan Kadar formaldehyde Pada Mie Basah yang Dijual Di Pasar Piyungan dengan Metode Spektrofotometri UV-VIS. 53(9), 1689-1699.

Male, Y. T., \& Letsoin, L. I. (2018). Analisis kandungan formaldehyde pada mie basah pada beberapa lokasi di kota ambon. 02(March), 5-10. 
Masturoh, I., \& Nauri, A. T. (2018). Metodologi Penelitian Kesehatan. Kementrian Kesehatan Republik Indonesia.

Modul Penanganan Mutu Fisis. (2013). Pengujian Organoleptik. Universitas Muhammadiyah Semarang, 31.

Nababan, D., Indriana, R., \& Sitepu, R. (2019). Analisis Kandungan Formaldehid Pada Tahu Yang Dijual Di Pasar Kota Medan. Jurnal Kesehatan Masyarakat Dan Lingkungan Hidup, 1(2), 1-10.

Nani, E., \& Wibowo, Y. M. (2019). Analisis Kandungan formaldehyde, Boraks, dan Protein dalam Mie Basah. Biomedika, 12(1), 67-73.

Nasution, S. (2017). Variabel penelitian. Raudhah, 05(02), 1-9.

Notoatmodjo, S. (2018). Metodologi Penelitian Kesehatan. RINEKA CIPTA.

Paratmanitya, Y., \& Veriani, A. (2016). Kandungan bahan tambahan pangan berbahaya pada makanan jajanan anak sekolah dasar di Kabupaten Bantul. Jurnal Gizi Dan Dietetik Indonesia (Indonesian Journal of Nutrition and Dietetics), 4(1), 49.

Prabhu, P. (2011). Detection and Quantification of Formaldehyde by Derivatization with Pentafluorobenzylhydroxyl Amine in Pharmaceutical Excipients by Static Headspace GC/MS. PerkinElmer App, 4.

Refwalu, M. H., Rorong, J. A., \& Sudewi, S. (2016). Analisis Kandungan formaldehyde Pada Berbagai Jenis Daging Di Pasar Swalayan Kota Manado. Pharmacon, 5(4), 168-173.

Rosita, N. (2020). Analisis Kandungan formaldehyde pada Tahu di Pasar Tradisional dan Pasar Swalayan Kota Tanggerang Selatan. Laporan Hasil Penelitian.

Roswiem, A. P., \& Septiani, T. (2018). Identifikasi Formaldehida Dalam Tahu Dan Mie Basah Pada Produk Pedagang Jajanan Di Sekitar Kampus Universitas YARSI Jakarta. YARSI Medical Journal, 26(3), 112-118.

Sari, T. M., Dira, \& Shinta. (2017). Analisis formaldehyde pada Ikan Asin Kembung di Beberapa Pasar di Kota Padang dengan Metoda Spektrofotometer UV-Vis. UNES Journal of Scientech Research (JSR), 2(2), 159-166.

Sikanna, R. (2016). Analisis Kualitatif Kandungan formaldehyde Pada Tahu Yang Dijual Dibeberapa Pasar Di Kota Palu. Kovalen, 2(2), 85-90.

Susanto, H., Latifah, E., \& Kusuma, T. M. (2015). Analisa Kualitatif Kandungan formaldehyde pada Tahu di Pasar Tradisional Kodya Magelang. Jurnal Farmasi Sains Dan Praktis, 1(1), 17-12.

Syafitri, W., Adang, F., \& Syarif, H. (2012). Skrining pereaksi spot test untuk deteksi kandungan formaldehyde pada bahan pangan. Indonesian Journal of Pharmaceutical Science and Technology, $1(2), 1-11$.

Syarfaini, \& Rusmin, M. (2014). Analisis Kandungan formaldehyde Pada Tahu di Pasar Tradisional Kota Makassar. Jurnal Kesehatan Masyarakat, 7(1), 1-11.

Tamsil, A., Akram, A., Budidaya, J., Fakultas, P., \& Kelautan, I. (2020). Bahaya Penggunaan formaldehyde Sebagai Pengawet Bahan Makanan. 4(1), 39-44.

Umanagara, S., \& Fahamsyah, E. (2020). Perlindungan Hukum Terhadap Konsumen Atas Produk Mie Basah yang Mengandung Fomalin. 3, 1071-1090.

Umbingo, S. C., Sudewi, S., \& Wewengkang, D. S. (2015). Validasi Metode Analisis formaldehyde Dalam Daging Paha Ayam Di Kota Manado. Pharmacon, 4(3), 139-146.

Yulianti, C.H, A. N. (2020). Analisis Kandungan formaldehyde pada Mie Basah Menggunakan Nash dengan Metode Spektrofotometri UV-Vis. Journal of Pharmacy and Science ,5(1),7-14. 132

Zackiyah. (2016). Spektrometri Ultra Violet/Sinar Tampak (UV-Vis). Kimia Analitik Instrumen, 1-46. 